\title{
Article
}

\section{The Response of Nutrient Uptake, Photosynthesis and Yield of Tomato to Biochar Addition under Reduced Nitrogen Application}

\author{
Lili Guo ${ }^{1,2,3}$, Huiwen $\mathrm{Yu}^{4, *}$, Mourad Kharbach ${ }^{5}(\mathbb{D})$ and Jingwei Wang ${ }^{6}(\mathbb{C}$ \\ 1 Department of Plant and Environmental Science, Faculty of Science, University of Copenhagen, \\ Højbakkegaard Alle 13, DK-2630 Taastrup, Denmark; mia@nwsuaf.edu.cn \\ 2 College of Water Resources and Architectural Engineering, Northwest A\&F University, Weihui Road 23, \\ Yangling 712100, China \\ 3 Key Laboratory of Agricultural Soil and Water Engineering in Arid and Semiarid Areas, \\ Ministry of Education, Northwest A\&F University, Yangling 712100, China \\ 4 Department of Food Science, Faculty of Science, University of Copenhagen, Rolighedsvej 26, \\ DK-1958 Frederiksberg C, Denmark \\ 5 Research Unit of Mathematical Sciences, University of Oulu, FI-90014 Oulu, Finland; \\ mourad.kharbach@hotmail.fr \\ 6 College of Resources and Environment, Shanxi University of Finance and Economics, Taiyuan 030000, China; \\ wjw@sxufe.edu.cn \\ * Correspondence: huiwen.yu@food.ku.dk
}

Citation: Guo, L.; Yu, H.;

Kharbach, M.; Wang, J. The Response of Nutrient Uptake, Photosynthesis and Yield of Tomato to Biochar Addition under Reduced Nitrogen Application. Agronomy 2021, 11, 1598. https://doi.org/10.3390/ agronomy11081598

Academic Editor: Sara Di Lonardo

Received: 3 July 2021

Accepted: 10 August 2021

Published: 11 August 2021

Publisher's Note: MDPI stays neutral with regard to jurisdictional claims in published maps and institutional affiliations.

Copyright: (c) 2021 by the authors. Licensee MDPI, Basel, Switzerland. This article is an open access article distributed under the terms and conditions of the Creative Commons Attribution (CC BY) license (https:// creativecommons.org/licenses/by/ $4.0 /)$.

\begin{abstract}
Tomato is an important economic crop that is widely consumed worldwide. Tomato production is mainly limited by the use of nitrogen fertilizer, sunlight, soil and water conditions. Biochar is one of the soil amendments, and it is recognized as a promising practice for improving crop production in agriculture. The effect of biochar on the photosynthetic traits and tomato yield under reduced nitrogen fertilizer application is still not well understood. The objective of this research is to investigate the influence of biochar application on the photosynthesis and yield of tomato under reduced nitrogen fertilizer application from the perspectives of the nutrient uptake of plants (nitrogen and phosphorus), leaf photosynthetic pigment and leaf gas exchange parameters. Two-year greenhouse experiments containing six biochar levels $\left(0,10,30,50,70\right.$, and $\left.90 \mathrm{tha}^{-1}\right)$ and two nitrogen fertilizer application rates (190 and $250 \mathrm{~kg} \mathrm{ha}^{-1}$ ) were conducted. Compared with C0, C50 significantly improved the nitrogen uptake (74-80\%) and phosphorus uptake (76-95\%) by tomato plants and further enhanced the photosynthetic traits of tomato leaves (net photosynthetic rate (Pn), stomatal conductance (gs), transpiration rate (Tr) and chlorophyll (2-60\%), which lead to the highest gains in tomato yield (more than 50\%) even when the applied nitrogen fertilizer was significantly reduced (from $250 \mathrm{~kg} \mathrm{ha}^{-1}$ to $190 \mathrm{~kg} \mathrm{ha}^{-1}$ ). The photosynthesis rate had a linear correlation with the total nitrogen and phosphorus accumulation and tomato yield. The results will enhance our understandings about the effect of biochar on the photosynthesis and yield of tomato and be of importance for practical agricultural management.
\end{abstract}

Keywords: biochar; nutrient uptake; gas exchange parameters; photosynthetic pigments; tomato yield

\section{Introduction}

Tomato is an important economic crop that is widely consumed worldwide. It is rich in phytonutrients, such as $\beta$-carotene and vitamin $C$ [1]. Because of its taste, flavors and nutrient content, tomato is widely grown in the world. It is reported that the global crop area of tomato has increased by $164 \%$, and the total consumption of tomatoes has increased by $314 \%$ during the past 40 years [2]. China is one of the biggest countries in terms of tomato production and consumption. The land area of tomato crops in China accounts for almost one third of the worldwide total [3]. However, tomato production is mainly limited by the use of nitrogen fertilizer, sunlight, soil and water conditions $[4,5]$. 
Biochar is a recognized promising amendment to improve crop production [6,7]. It is a carbon solid material that is produced from biomass by low-temperature pyrolysis [8-10]. Many studies have reported that biochar was a useful choice for improving water condition and soil characteristics, promoting crop growth and production and reducing environmental pollution in agricultural practice [11-13]. Previous studies showed that biochar affected the nutrient uptake of plants by changing the nutrient release dynamics of the soil-plant system [14-16]. For example, biochar addition increased soil water-holding capacity and nitrogen adsorption and enhanced $\mathrm{N}$ immobilization, which led to a reduction in nitrogen leaching and an increase in bioavailability and maize yield [17]. Recently, it has been reported that biochar had the potential of enhancing the nutrient accumulation $(\mathrm{N})$ and photosynthesis of plants [18]. The addition of biochar into paddy soil has been shown to improve the plant height, biomass and photosynthesis of rice [19]. Furthermore, biochar was recognized to positively impact the Pn, chlorophyll index, nitrogen balance index and leaf soluble sugar of soybean, and the effects increased as the biochar application rate increased [20]. It was expected to boost the positive effects when the $\mathrm{N}$ fertilizer was applied together. As a soil amendment, biochar improved the water and nutrient status of phragmites karka, which led to an increase in net photosynthesis and a higher energy-use efficiency of the photosystem for phragmites karka [21]. Moreover, there was also evidence suggesting that biochar stimulated plant photosynthesis and growth by changing root traits and stimulating the root growth of crops [22]. Water supply conditions was also shown to impact the change in photosynthetic traits of leaves, which further impacted the yield of crops [23,24].

Biochar amendment can impact the growth and productivity of tomato. For example, adding $5 \%, 10 \%$ or $15 \%$ biochar in a peat-based growing medium improved tomato plant water-use efficiency, and increased tomato fruit dry-weight yield by up to $32 \%$ [25]. When the biochar was added into coconut fiber-tuff, the tomato yield increased significantly [26]. Although the available literature documented a general improvement in crop response under biochar amendment, there were still notable exceptions. A recent study showed that biochar cannot significantly improve tomato yield under nutritional stress [27]. In the fertile soil, adding $14 \mathrm{t}$ ha -1 biochar stimulated plant growth but not the yield of processed tomato [28]. Meanwhile, many reports have studied the impact of nitrogen supply on tomato. During the growing season, lowering nitrogen supply (the nitrate concentration was lowered from $12 \mathrm{mM}$ to $4 \mathrm{mM}$ or $6 \mathrm{mM}$ ) had an impact on tomato yield $(-7.5 \%)$, but it increased fruit dry-matter content and also improved fruit quality due to lower acid (10-16\%) and higher soluble sugar content (5-17\%) [29]. In a silty-clay soil under Mediterranean conditions, increasing the $\mathrm{N}$ supply from $200 \mathrm{~kg} \mathrm{ha}^{-1}$ to $300 \mathrm{~kg} \mathrm{ha}^{-1}$ resulted in lower total and marketable tomato yield [30]. Therefore, the maximum tomato yield and $\mathrm{N}$ use efficiency were obtained at the $\mathrm{N}$ rate of $200 \mathrm{~kg} \mathrm{ha}^{-1}$. Recently, it has been shown that reducing the $\mathrm{N}$ supply (from $14 \mathrm{mM}$ to $3 \mathrm{mM}$ in nutrient solution) had different effect on tomato yield when the reduction was imposed from transplant or anthesis [31]. Overall, the available results regarding the relationship among biochar, $\mathrm{N}$ and tomato are variable. Furthermore, there is little information available about the synergistic effect of biochar and $\mathrm{N}$ on tomato plant growth and yield.

Photosynthesis is important for tomato plant growth and its yield. Most available studies investigating the photosynthesis of tomato focused on the effect of pathogens, light intensity, temperature and genes, etc. [32-34]. Little information was known about the effect of biochar on the photosynthetic traits of tomato under reduced $\mathrm{N}$ fertilizer application. In this paper, we investigated the effect of biochar application on the photosynthesis of tomato from the perspectives of nutrient uptake of plants ( $\mathrm{N}$ and phosphorus (P), leaf photosynthetic pigment and leaf gas exchange parameters. Considering the aim of the investigation, the following hypotheses were proposed: (1) Biochar improved the yield of tomato by enhancing its leaf photosynthetic traits under reduced $\mathrm{N}$ fertilizer application. (2) Biochar improved the leaf photosynthetic pigment content and leaf gas exchange parameters of tomato due to the increasing nutrient uptake of plants ( $\mathrm{N}$ and $\mathrm{P}$ ) under reduced $\mathrm{N}$ fertilizer application. 


\section{Materials and Methods}

\subsection{Experimental Site and Setup}

Two-year greenhouse experiments were carried out from 2 September 2017 to 10 February 2018 (the first year) and from 6 April 2018 to 1 August 2018 (the second year), respectively, in Yangling City, Shaanxi Province, China. The greenhouse was $108 \mathrm{~m}$ in length and $8 \mathrm{~m}$ in width. The soil in the greenhouse was classified as a silty clay loam with a bulk density of $1.35 \mathrm{~g} \mathrm{~cm}^{-3}$. Regarding to the physical and chemical properties of the soil, it had a field capacity of $27.98 \%$, a $\mathrm{pH}$ of 7.35 , a soil porosity of $49.01 \%$, and its organic matter content was $16.48 \mathrm{~g} \mathrm{~kg}^{-1}$; total $\mathrm{N}$ was $0.96 \mathrm{~g} \mathrm{~kg}^{-1}$; total $\mathrm{P}$ was $0.87 \mathrm{~g} \mathrm{~kg}^{-1}$, and total $\mathrm{K}$ was $10.4 \mathrm{~g} \mathrm{~kg}^{-1}$. The used biochar was produced from the trunks and branches of discarded fruit trees, pyrolyzed at $450{ }^{\circ} \mathrm{C}$ and manufactured by Shaanxi Yixin Bioenergy Technology Development Co., Ltd., Yangling City, Shaanxi Province, China. The surface area of the biochar was $87.1 \mathrm{~m}^{2} \mathrm{~g}^{-1}$. Its $\mathrm{pH}$ value, amount of carbon, total ash, total $\mathrm{N}, \mathrm{NO}_{3}{ }^{-}-\mathrm{N}$ and $\mathrm{NH}_{4}{ }^{+}-\mathrm{N}$ were $10.51 \%, 72.38 \%$, $19.8 \%, 0.98 \mathrm{~g} \mathrm{~kg}^{-1}, 0.59 \mathrm{mg} \mathrm{kg}^{-1}$ and $1.67 \mathrm{mg} \mathrm{kg}^{-1}$, respectively. The "Dorui Star" cultivar sold by Seedling Breeding Center of Yangling Demonstration Area (Yangling City, Shaanxi Province) was used for the experiments. Drip irrigation pipes (Shaanxi Huawei Agricultural Science and Technology Development Co., Ltd., Yangling City, Shaanxi Province, China) were laid on the ground. The length of the pipes was the same as the ridge length $(5.5 \mathrm{~m})$.

Considering the experimental setups in Du, et al. [35] and Guo, et al. [36], six biochar application levels $\left(\mathrm{C} 0,0 \mathrm{t} \mathrm{ha}^{-1}\right.$; $\mathrm{C} 10,10 \mathrm{t} \mathrm{ha}^{-1}$; C30, $30 \mathrm{t} \mathrm{ha}^{-1}$; $\mathrm{C} 50,50 \mathrm{tha}^{-1}$; C70, $\left.70 \mathrm{tha}^{-1} ; \mathrm{C} 90,90 \mathrm{tha}^{-1}\right)$ and two $\mathrm{N}$ fertilizer application rates $\left(\mathrm{N} 1,190 \mathrm{~kg} \mathrm{ha}^{-1}\right.$ and $\mathrm{N} 2$, $250 \mathrm{~kg} \mathrm{ha}^{-1}, \mathrm{~N}=46 \%$ by weight) were designed in this experiment. N2 was the normal amount of $\mathrm{N}$ fertilizer applied by local farmers in the area. A total of 12 treatments were designed and named N1C0, N1C10, N1C30, N1C50, N1C70, N1C90, N2C0, N2C10, N2C30, $\mathrm{N} 2 \mathrm{C} 50, \mathrm{~N} 2 \mathrm{C} 70$ and $\mathrm{N} 2 \mathrm{C} 90$. In the experiments, each treatment occupied a block in the greenhouse. For each block, it was composed by three small plots (representing three replicates for the same treatment). The tomato seedlings were transplanted at the fourth leaf stage. A total of 30 plants were transplanted in each plot in double rows with a row distance of $40 \mathrm{~cm}$ and a plant spacing of $45 \mathrm{~cm}$, and 90 plants were transplanted in each block, which resulted in a total of 1080 plants in each experiment. The plots were irrigated up to $90 \%$ field capacity (FC) when the soil moisture content was lower than $60 \%$ FC. The applied $\mathrm{P}$ and $\mathrm{K}$ fertilizer were phosphorus $\left(\mathrm{P}_{2} \mathrm{O}_{5}=16 \%\right.$ by weight $)$ and potassium sulfate $\left(\mathrm{K}_{2} \mathrm{O}=51 \%\right.$ by weight), respectively. The setups were the same for the two experiments. In the first year of the experiment, the biochar (passed through a $4 \mathrm{~mm}$ sieve) was applied to the $0-30 \mathrm{~cm}$ soil layer by plowing with a rotary tiller. Then the N, P and K fertilizer were applied. In the second year, no additional biochar was applied, and only the N, P and K fertilizers were applied.

\subsection{Measurements}

\subsection{1. $\mathrm{N}$ and $\mathrm{P}$ Uptake of Tomato Plants}

During the fruiting stage of the experiments (40-80 days after planting), 15 tomato plant samples were collected in each block. For each sample, soil in the root was removed, and the root was washed with fresh water. They were then separated into various parts: roots, stems, leaves and fruits. The samples were oven-dried at $105^{\circ} \mathrm{C}$ for $30 \mathrm{~min}$ and then at $75^{\circ} \mathrm{C}$ to constant weight. The oven-dried samples of roots, stems, leaves and fruits were ground and passed through a $0.5 \mathrm{~mm}$ sieve. Then they were digested with $\mathrm{H}_{2} \mathrm{SO}_{4}$ (5 mL)- $\mathrm{H}_{2} \mathrm{O}_{2}(3-6 \mathrm{~mL})$. A Kjeldahl nitrogen analyzer (FOSS 2300) was used for $\mathrm{N}$ content analysis. The vanadium molybdenum yellow absorbance colorimetric method [37] was used to determine $\mathrm{P}$ content. $\mathrm{N}$ accumulation was calculated by multiplying $\mathrm{N}$ content in roots, stems, leaves and fruits with the respective plant dry-matter and summing them together. The $\mathrm{P}$ accumulation was calculated in the same way. 


\subsubsection{Tomato Leaf Gas Exchange Parameters}

For each small plot, five plants were randomly selected. A total of 15 plants were measured for each treatment (block). During the fruiting stage of the experiments, five healthy leaves with sufficient light exposure and consistent leaf position and without visible symptoms of damage were selected from each plant. The net photosynthetic rate $(\mathrm{Pn})$, stomatal conductance (gs) and transpiration rate (Tr) of the leaves were measured by the LI-6400 photosynthesis measurement system (LI-COR, Lincoln, NE, USA) [38] at 10:00 a.m. $-12: 00$ p.m.

\subsubsection{Tomato Leaf Photosynthetic Pigment}

The leaves that have been measured in Section 2.2.2 were also used for the determination of chlorophyll $\mathrm{a}, \mathrm{b}$ and $\mathrm{a}+\mathrm{b}$ contents. Circular pieces were cut from the selected leaves and they were then extracted with $95 \%$ ethanol. The final extracts were measured using a spectrophotometer [39], and the absorbance values at $665 \mathrm{~nm}$ and $649 \mathrm{~nm}$ were recorded. Then the contents of chlorophyll $\mathrm{a}, \mathrm{b}$ and $\mathrm{a}+\mathrm{b}$ were determined.

\subsubsection{Tomato Yield}

In each experiment, 15 tomato plants were harvested from each block. Fruits of tomato plants from the first to the fourth layer were measured in turn, and then the total fresh weight of these four layers fruit were calculated as the total yield for each plant.

\subsubsection{Statistical Analysis}

The experimental data was analyzed using SPSS version 23.0 software (SPSS Inc., Chicago, IL, USA). In order to test the significant difference in the parameters among the treatments, two-way analysis of variance (ANOVA) was performed. $\mathrm{N}$, biochar application and year were supposed to be fixed factors. The means were compared using Duncan's multiple range test at the 0.05 probability level. The relationship between Pn and total $\mathrm{N}$ and $\mathrm{P}$ accumulation and the relationship between $\mathrm{Pn}$ and tomato yield were tested using regression analysis. The responses of nutrient uptake ( $\mathrm{N}$ and $\mathrm{P}$ ), gas exchange parameters, photosynthetic pigment content and tomato yield to biochar and $\mathrm{N}$ application were further analyzed with principal component analysis using MATLAB R2018a software (The MathWorks, Inc., Natick, MA, USA).

\section{Results}

\subsection{The N and P Uptake of Tomato Plants \\ 3.1.1. N Uptake}

The effect of biochar on the total $\mathrm{N}$ accumulation of root, stem, leaf and fruit was significant, and there was significant difference for $\mathrm{N}$ fertilizer application, year, $\mathrm{N} \times \mathrm{C}$, $\mathrm{Y} \times \mathrm{C}$ and $\mathrm{Y} \times \mathrm{N} \times \mathrm{C}$ (Table 1). In 2017, the order of $\mathrm{N}$ content in different organs was: fruit > leaf > stem > root; in 2018, the order of $N$ content in different organs was: stem $>$ fruit $>$ leaf $>$ root. The total $\mathrm{N}$ accumulation first increased and then decreased with the increase of biochar application, and the treatment of C50 was the largest for both N1 and N2 in 2017 and 2018 (Figure 1).

In 2017, the total N accumulation of C10, C30, C50, C70 and C90 in the N1 treatment group increased by $10.33 \%, 34.97 \%, 74.82 \%, 67.07 \%$ and $34.07 \%$, with respect to $\mathrm{C} 0$. The total $\mathrm{N}$ accumulation of N1C50 reached the maximum. Compared with $\mathrm{C} 0$, the total $\mathrm{N}$ accumulation of C10, C30, C50, C70 and C90 in the N2 treatment group increased by $12.91 \%$, $36.92 \%, 54.49 \%, 49.47 \%$ and $22.29 \%$, and the N2C50 was the maximum. For C50 and C70, there was no significant difference in the total $\mathrm{N}$ accumulation between $\mathrm{N} 1$ and $\mathrm{N} 2$.

In 2018, the total $\mathrm{N}$ accumulation of $\mathrm{C} 10, \mathrm{C} 30, \mathrm{C} 50, \mathrm{C} 70$ and $\mathrm{C} 90$ in the $\mathrm{N} 1$ treatment group increased by $18.70 \%, 74.99 \%, 80.07 \%, 79.68 \%$ and $51.26 \%$, with respect to C0. The N1C50 reached the maximum. Compared with $\mathrm{C} 0$, the total $\mathrm{N}$ accumulation of $\mathrm{C} 10, \mathrm{C} 30$, C50, C70 and C90 in the N2 treatment group increased by $20.75 \%, 49.95 \%, 65.99 \%, 37.24 \%$ and $25.58 \%$, and the $\mathrm{N} 2 \mathrm{C} 50$ was the maximum. For C30, C50, C70 and C90, there was no significant difference in the total $\mathrm{N}$ accumulation between $\mathrm{N} 1$ and $\mathrm{N} 2$. 
Table 1. Output of two-way ANOVA of N accumulation, P accumulation, Pn, gs, Tr, chlorophyll a, chlorophyll b, chlorophyll $\mathrm{a}+\mathrm{b}$ and yield as affected by $\mathrm{N}$ (N1 and N2), biochar (C0, C10, C30, C50, C70 and C90) and year (2017 and 2018$)$. ${ }^{*}, * *$ and ${ }^{* * *}$ indicate significance levels at $p<0.05, p<0.01$ and $p<0.001$, respectively, and ns denotes no significance.

\begin{tabular}{|c|c|c|c|c|c|c|c|c|c|}
\hline Factors & N Accumulation & P Accumulation & Pn & gs & $\operatorname{Tr}$ & Chlorophyll a & Chlorophyll b & Chlorophyll $a+b$ & Yield \\
\hline $\mathrm{N}$ & $* * *$ & $*$ & ns & ns & ns & ns & $*$ & ns & $* * *$ \\
\hline $\mathrm{C}$ & $* * *$ & $* * *$ & $* * *$ & $* * *$ & $* * *$ & $* * *$ & $* * *$ & $* * *$ & $* * *$ \\
\hline Y & $* * *$ & $* * *$ & $* * *$ & $* * *$ & $* * *$ & ns & $* * *$ & $* *$ & $* * *$ \\
\hline $\mathrm{N} \times \mathrm{C}$ & $* * *$ & ns & $* * *$ & $* * *$ & ns & ns & ns & ns & $* * *$ \\
\hline $\mathrm{Y} \times \mathrm{N}$ & ns & ns & ns & ns & ns & $*$ & $*$ & $*$ & $* * *$ \\
\hline $\mathrm{Y} \times \mathrm{C}$ & $* * *$ & $* * *$ & $* * *$ & $* * *$ & $* * *$ & ns & ns & ns & $* * *$ \\
\hline $\mathrm{Y} \times \mathrm{N} \times \mathrm{C}$ & * & ns & $*$ & ns & $*$ & ns & $\mathrm{ns}$ & ns & $* * *$ \\
\hline
\end{tabular}

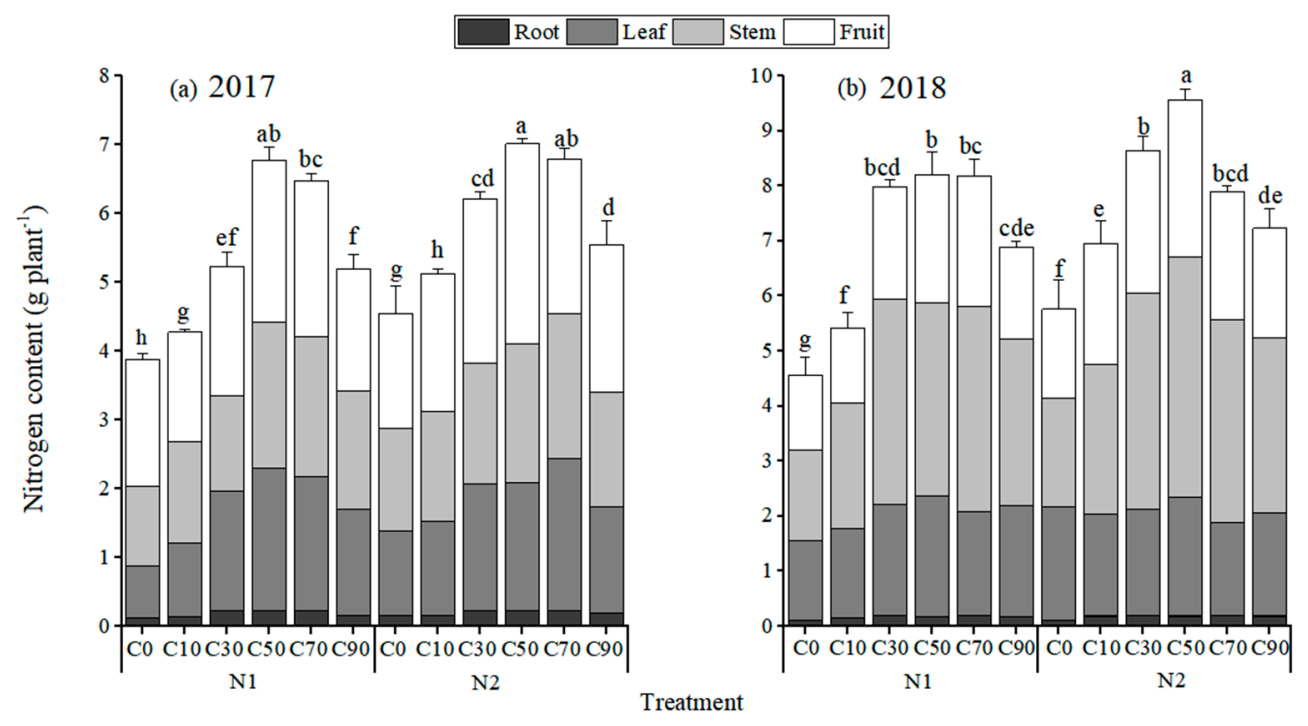

Figure 1. The effect of biochar on the N uptake of tomato plants under low (N1) and normal (N2) nitrogen fertilization in 2017 (a) and 2018 (b). Different lowercase letters denote significant differences among treatment means at the 0.05 level by Duncan's MRT method.

\subsubsection{P Uptake}

Biochar had a significant effect on the total $\mathrm{P}$ accumulation of tomato plants, as did $\mathrm{N}$ fertilizer, year and $\mathrm{Y} \times \mathrm{C}$ (Table 1), while there were no significant differences for $\mathrm{N} \times \mathrm{C}$, $\mathrm{Y} \times \mathrm{N}$ and $\mathrm{Y} \times \mathrm{N} \times \mathrm{C}$. On average, the order of $\mathrm{P}$ content in different organs was as follows: fruit $>$ leaf $>$ stem $>$ root. The total $\mathrm{P}$ accumulation showed a trend of first increasing and then diminishing as the amount of applied biochar increased, and it reached the maximum in C50 for both N1 and N2 in 2017 and 2018 (Figure 2).

In 2017, the total P accumulation of C10, C30, C50, C70 and C90 in the N1 treatment group increased by $34.34 \%, 49.27 \%, 76.04 \%, 63.84 \%$ and $32.66 \%$, with respect to $\mathrm{C} 0$. The total $\mathrm{P}$ accumulation of N1C50 reached the maximum. Compared with $\mathrm{C} 0$, the total $\mathrm{P}$ accumulation of $\mathrm{C} 10, \mathrm{C} 30, \mathrm{C} 50, \mathrm{C} 70$ and $\mathrm{C} 90$ in the $\mathrm{N} 2$ treatment group increased by $5.94 \%, 18.53 \%, 25.05 \%, 11.48 \%$ and $4.22 \%$, and the N2C50 was the maximum. For C10, C30, C50, C70 and C90, they all had no significant difference in the total $\mathrm{P}$ accumulation between $\mathrm{N} 1$ and $\mathrm{N} 2$.

In 2018, the total P accumulation of $\mathrm{C} 10, \mathrm{C} 30, \mathrm{C} 50, \mathrm{C} 70$ and $\mathrm{C} 90$ in the $\mathrm{N} 1$ treatment group increased by $21.67 \%, 89.87 \%, 94.82 \%, 74.45 \%$ and $34.90 \%$, with respect to C0. The total $\mathrm{P}$ accumulation of N1C50 reached the maximum. Compared with $\mathrm{C} 0$, the total $\mathrm{P}$ accumulation of $\mathrm{C} 10, \mathrm{C} 30, \mathrm{C} 50, \mathrm{C} 70$ and $\mathrm{C} 90$ in the $\mathrm{N} 2$ treatment group increased by $16.41 \%, 82.61 \%, 88.57 \%, 70.57 \%$ and $2.38 \%$, and the N2C50 was the maximum. For C10, C30. C50, C70 and C90, there was no significant difference in the total P accumulation between $\mathrm{N} 1$ and $\mathrm{N} 2$. 


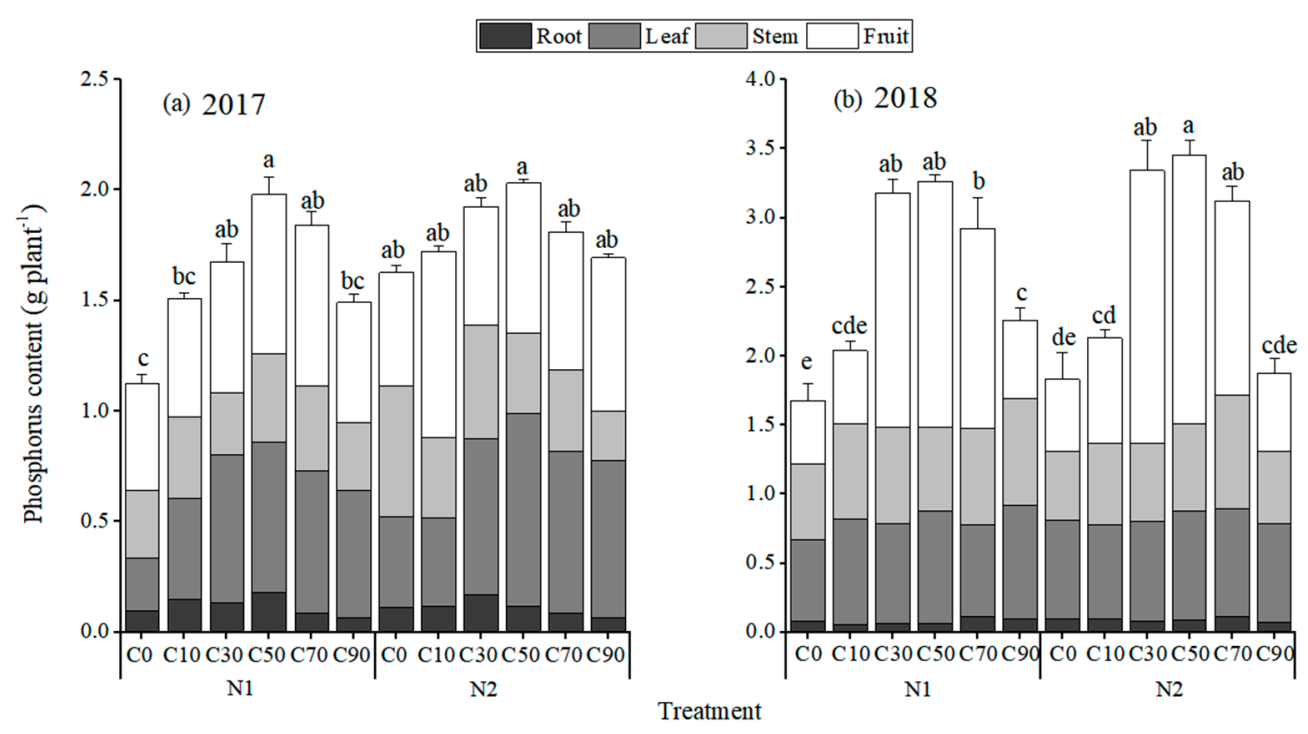

Figure 2. The effect of biochar on P uptake of tomato plants under low (N1) and normal (N2) nitrogen fertilization in 2017 (a) and 2018 (b). Different lowercase letters denote significant differences among treatment means at the 0.05 level by Duncan's MRT method.

\subsection{Gas Exchange Parameters of Tomato Leaves}

The effects of biochar on Pn, gs and Tr of tomato leaves were significant, as well as year and $\mathrm{Y} \times \mathrm{C}$ (Table 1). $\mathrm{N} \times \mathrm{C}$ had a significant effect on Pn and gs while it did not have significant effect on Tr. $\mathrm{Y} \times \mathrm{N} \times \mathrm{C}$ had a significant influence on Pn and Tr, but it did not have significant effects on gs. Overall, Pn, gs and Tr first increased and then decreased as the amount of applied biochar increased (Table 2).

Table 2. The effects of biochar on gas exchange parameters in tomato leaves under low (N1) and normal (N2) nitrogen fertilization in 2017 and 2018. Different lowercase letters denote significant differences among treatment means at the 0.05 level by Duncan's MRT method.

\begin{tabular}{|c|c|c|c|c|c|c|c|}
\hline \multirow{2}{*}{\multicolumn{2}{|c|}{ Treatment }} & \multicolumn{2}{|c|}{$\operatorname{Pn}\left(\mathrm{mmol} \mathrm{m}^{-2} \mathrm{~s}^{-1}\right)$} & \multicolumn{2}{|c|}{ Gs $\left(\mathrm{mol} \mathrm{m}^{-2} \mathrm{~s}^{-1}\right)$} & \multicolumn{2}{|c|}{$\operatorname{Tr}\left(\mathrm{mmol} \mathrm{m} \mathrm{m}^{-2} \mathrm{~s}^{-1}\right)$} \\
\hline & & 2017 & 2018 & 2017 & 2018 & 2017 & 2018 \\
\hline \multirow{6}{*}{ N1 } & $\mathrm{C} 0$ & $23.68 \mathrm{f}$ & $25.25 \mathrm{e}$ & $0.26 \mathrm{~g}$ & $0.39 \mathrm{e}$ & $9.81 \mathrm{~g}$ & $10.16 \mathrm{f}$ \\
\hline & $\mathrm{C} 10$ & $25.29 \mathrm{e}$ & $27.31 \mathrm{~d}$ & $0.30 \mathrm{f}$ & $0.41 \mathrm{de}$ & 10.80 ef & $11.93 \mathrm{e}$ \\
\hline & $\mathrm{C} 30$ & $\begin{array}{l}27.95 \\
\text { abcd }\end{array}$ & $29.96 \mathrm{c}$ & $0.36 \mathrm{abc}$ & $0.49 \mathrm{c}$ & $11.63 \mathrm{~d}$ & $13.75 \mathrm{bc}$ \\
\hline & C50 & $28.67 \mathrm{a}$ & $32.77 \mathrm{~b}$ & $0.38 \mathrm{ab}$ & $0.62 \mathrm{a}$ & $12.73 \mathrm{c}$ & $14.27 \mathrm{ab}$ \\
\hline & $\mathrm{C} 70$ & $28.29 \mathrm{abc}$ & $35.20 \mathrm{a}$ & $0.39 \mathrm{a}$ & $0.57 \mathrm{ab}$ & $13.71 \mathrm{ab}$ & $14.74 \mathrm{a}$ \\
\hline & C90 & $27.35 \mathrm{bcd}$ & $34.18 \mathrm{ab}$ & $0.35 \mathrm{bcd}$ & $0.51 \mathrm{bc}$ & $13.26 \mathrm{abc}$ & $13.31 \mathrm{c}$ \\
\hline \multirow{6}{*}{ N2 } & $\mathrm{C} 0$ & $26.77 \mathrm{~d}$ & $25.08 \mathrm{e}$ & 0.32 ef & 0.46 cde & $10.46 \mathrm{fg}$ & $11.57 \mathrm{e}$ \\
\hline & $\mathrm{C} 10$ & $27.04 \mathrm{~cd}$ & $26.05 \mathrm{de}$ & 0.34 cde & $0.47 \mathrm{~cd}$ & $11.30 \mathrm{de}$ & $12.58 \mathrm{~d}$ \\
\hline & $\mathrm{C} 30$ & $\begin{array}{l}27.99 \\
\text { abcd }\end{array}$ & $27.07 \mathrm{~d}$ & $0.38 \mathrm{ab}$ & $0.50 \mathrm{bc}$ & $12.50 \mathrm{c}$ & $13.44 \mathrm{c}$ \\
\hline & C50 & $28.45 \mathrm{ab}$ & $33.61 \mathrm{~b}$ & $0.36 \mathrm{abc}$ & $0.61 \mathrm{a}$ & $13.25 \mathrm{abc}$ & $14.27 \mathrm{ab}$ \\
\hline & $\mathrm{C} 70$ & $\begin{array}{l}27.87 \\
\text { abcd }\end{array}$ & $34.29 \mathrm{ab}$ & $0.35 \mathrm{bcd}$ & $0.52 \mathrm{bc}$ & $14.07 \mathrm{a}$ & $14.41 \mathrm{a}$ \\
\hline & C90 & $27.36 \mathrm{bcd}$ & $33.74 \mathrm{ab}$ & 0.33 de & $0.52 \mathrm{bc}$ & $13.15 \mathrm{bc}$ & $14.48 \mathrm{a}$ \\
\hline \multicolumn{2}{|c|}{ Mean } & 27.23 & 30.38 & 0.34 & 0.51 & 12.22 & 13.24 \\
\hline
\end{tabular}

In 2017, the C10, C30, C50, C70 and C90 in N1 treatment group increased Pn by $6.83 \%, 18.05 \%, 21.08 \%, 19.48 \%$ and $15.53 \%$, with respect to C 0 . The Pn of N1C50 reached the maximum. Compared with C0, the Pn of C10, C30, C50, C70 and C90 in the N2 treatment group increased by $1 \%, 5.54 \%, 6.25 \%, 4.08 \%$ and $2.20 \%$, and the $\mathrm{N} 2 \mathrm{C} 50$ is the maximum. For C30, C50, C70 and C90, there was no significant difference in Pn between 
N1 and N2. In 2018, N1C70 and N2C70 increased the Pn by $39.42 \%$ and $36.71 \%$, which are the maximum in the $\mathrm{N} 1$ and $\mathrm{N} 2$ groups, respectively.

In 2017, the C10, C30, C50, C70 and C90 in the N1 treatment group increased gs by $13.94 \%, 37.98 \%, 44.32 \%, 49.37 \%$ and $34.18 \%$, with respect to $\mathrm{C} 0$. The gs of $\mathrm{N} 1 \mathrm{C} 70$ reached the maximum. Compared with $\mathrm{C} 0$, the gs of $\mathrm{C} 10, \mathrm{C} 30, \mathrm{C} 50, \mathrm{C} 70$ and $\mathrm{C} 90$ in the $\mathrm{N} 2$ treatment group increased by $6.25 \%, 18.75 \%, 13.53 \%, 10.41 \%$ and $3.13 \%$, and the $\mathrm{N} 2 \mathrm{C} 30$ is the maximum. For C30, C50 and C90, there was no significant difference in gs between N1 and N2. For C70, the gs of N1 is significantly higher than N2. In 2018, N1C50 and N2C50 increased the gs by $58.97 \%$ and $32.61 \%$ which are the maximum in the $\mathrm{N} 1$ and $\mathrm{N} 2$ groups, respectively.

In 2017, the C10, C30, C50, C70 and C90 in the N1 treatment group increased Tr by $10.05 \%, 18.51 \%, 29.76 \%, 39.74 \%$ and $35.09 \%$, with respect to $\mathrm{C} 0$. The Tr of N1C70 reached the maximum. Compared with C0, the Tr of C10, C30, C50, C70 and C90 in the N2 treatment group increased by $8.03 \%, 19.47 \%, 26.66 \%, 34.57 \%$ and $25.65 \%$, and the $\mathrm{N} 2 \mathrm{C} 70$ was the maximum. For C10, C50, C70 and C90, no significant difference was shown in Tr between N1 and N2. In 2018, N1C70 increased the Tr by 45.08\%, which was the maximum.

\subsection{Photosynthetic Pigments in Tomato Leaves}

Biochar had significant effects on the content of chlorophyll $a, b$ and $a+b$ of tomato leaves, as well as $\mathrm{Y} \times \mathrm{N}$ (Table 1). $\mathrm{N}$ application had a significant effect on chlorophyll $\mathrm{b}$, while it did not have a significant effect on chlorophyll $\mathrm{a}$ or $\mathrm{a}+\mathrm{b}$. Year had significant effects on chlorophyll $b$ and $a+b$, but there was no significant effect on chlorophyll $a$. The content of these photosynthetic pigments in tomato leaves first increased and then decreased as the amount of applied biochar increased, and they achieved the maximum either at C30 or C50 treatment in 2017 and 2018 (Table 3).

Table 3. The effects of biochar on photosynthetic pigments in tomato leaves under low (N1) and normal (N2) nitrogen fertilization in 2017 and 2018. Different lowercase letters denote significant differences among treatment means at the 0.05 level by Duncan's MRT method.

\begin{tabular}{|c|c|c|c|c|c|c|c|}
\hline \multirow{2}{*}{\multicolumn{2}{|c|}{ Treatment }} & \multicolumn{2}{|c|}{ Chlorophyll a/mg.g } & \multicolumn{2}{|c|}{ Chlorophyll b/mg.g } & \multicolumn{2}{|c|}{ Chlorophyll $a+b / m g . g$} \\
\hline & & 2017 & 2018 & 2017 & 2018 & 2017 & 2018 \\
\hline \multirow{6}{*}{ N1 } & $\mathrm{C} 0$ & 1.69 cde & $1.82 \mathrm{ab}$ & $0.71 \mathrm{~cd}$ & $0.63 \mathrm{abcd}$ & $2.40 \mathrm{bcd}$ & $2.46 \mathrm{ab}$ \\
\hline & $\mathrm{C} 10$ & $1.82 \mathrm{bcd}$ & $1.86 \mathrm{ab}$ & $0.72 \mathrm{~cd}$ & $0.66 \mathrm{abc}$ & $2.55 \mathrm{bc}$ & $2.52 \mathrm{ab}$ \\
\hline & C30 & $1.93 \mathrm{abc}$ & $1.92 \mathrm{a}$ & $0.81 \mathrm{abc}$ & $0.67 \mathrm{ab}$ & $2.73 \mathrm{ab}$ & $2.59 \mathrm{a}$ \\
\hline & C50 & $1.81 \mathrm{bcd}$ & $1.86 \mathrm{ab}$ & $0.73 \mathrm{~cd}$ & 0.65 abcd & $2.53 \mathrm{bc}$ & $2.50 \mathrm{ab}$ \\
\hline & C70 & 1.68 cde & $1.76 \mathrm{abc}$ & $0.67 \mathrm{~d}$ & $0.58 \mathrm{def}$ & $2.34 \mathrm{~cd}$ & $2.34 \mathrm{abc}$ \\
\hline & C90 & $1.50 \mathrm{e}$ & $1.52 \mathrm{~d}$ & $0.56 \mathrm{e}$ & $0.52 \mathrm{f}$ & $2.06 \mathrm{~d}$ & $2.04 \mathrm{~d}$ \\
\hline \multirow{6}{*}{ N2 } & $\mathrm{CO}$ & 1.76 cde & $1.72 \mathrm{abc}$ & $0.71 \mathrm{~cd}$ & 0.59 cde & $2.47 \mathrm{bc}$ & $2.32 \mathrm{bc}$ \\
\hline & $\mathrm{C} 10$ & $2.12 \mathrm{a}$ & $1.75 \mathrm{abc}$ & $0.87 \mathrm{a}$ & $0.61 \mathrm{bcd}$ & $2.98 \mathrm{a}$ & $2.36 \mathrm{abc}$ \\
\hline & C30 & $2.08 \mathrm{ab}$ & $1.89 \mathrm{ab}$ & $0.84 \mathrm{ab}$ & $0.69 \mathrm{a}$ & $2.92 \mathrm{a}$ & $2.58 \mathrm{a}$ \\
\hline & C50 & 1.78 cde & $1.87 \mathrm{ab}$ & $0.75 \mathrm{bcd}$ & $0.64 \mathrm{abcd}$ & $2.53 \mathrm{bc}$ & $2.51 \mathrm{ab}$ \\
\hline & C70 & 1.70 cde & $1.70 \mathrm{bcd}$ & $0.71 \mathrm{~cd}$ & 0.60 cde & $2.41 \mathrm{bcd}$ & $2.29 \mathrm{bc}$ \\
\hline & C90 & $1.59 \mathrm{de}$ & $1.59 \mathrm{~cd}$ & $0.65 \mathrm{de}$ & 0.54 ef & $2.24 \mathrm{~cd}$ & $2.13 \mathrm{~cd}$ \\
\hline \multicolumn{2}{|c|}{ Mean } & 1.79 & 1.77 & 0.73 & 0.61 & 2.51 & 2.39 \\
\hline
\end{tabular}

In 2017, the $\mathrm{C} 10, \mathrm{C} 30, \mathrm{C} 50, \mathrm{C} 70$ and $\mathrm{C} 90$ in the $\mathrm{N} 1$ treatment group increased chlorophyll a by $7.68 \%, 13.78 \%, 6.69 \%,-0.98 \%$ and $-11.42 \%$, with respect to C 0 . The chlorophyll a of N1C30 reached the maximum. Compared with C0, the chlorophyll a of C10, C30, C50, C70 and C90 in the N2 treatment group increased by $20.27 \%, 7.99 \%, 0.95 \%,-3.41 \%$ and $-9.47 \%$, and the $\mathrm{N} 2 \mathrm{C} 10$ is the maximum. For C30, C50, C70 and C90, there was no significant difference in chlorophyll a between N1 and N2. In 2018, N1C30 and N2C30 increased the chlorophyll a by $5.48 \%$ and $9.86 \%$, which are the maximum in the N1 and N2 groups, respectively.

In 2017, the C10, C30, C50, C70 and C90 in the N1 treatment group increased chlorophyll b by $2.36 \%, 14.15 \%, 2.83 \%,-5.66 \%$ and $-21.23 \%$, with respect to C 0 . The chlorophyll 
b of N1C30 reached the maximum. Compared with $\mathrm{C} 0$, the chlorophyll b of C10, C30, C50, C70 and C90 in the N2 treatment group increased by $22.64 \%, 18.87 \%, 6.13 \%, 0.47 \%$ and $-8.49 \%$, and the $\mathrm{N} 2 \mathrm{C} 10$ is the maximum. For C30, C50, C70 and C90, there was no significant difference in chlorophyll b between N1 and N2. In 2018, N1C30 and N2C30 increased the chlorophyll b by $5.26 \%$ and $15.73 \%$, which are the maximum in the N1 and N2 groups, respectively. Similar to the case of chlorophyll a, applying excessive biochar, for example C90, always results in lower content of chlorophyll b than C0.

In 2017, N1C30 and N2C10 reached the maximum in the N1 and N2 groups, which increased the content of chlorophyll $\mathrm{a}+\mathrm{b}$ by $13.89 \%$ and $20.94 \%$ in $\mathrm{N} 1$ and $\mathrm{N} 2$, respectively. In 2018, N1C30 and N2C30 reached the maximum in the N1 and N2 groups, which increased the content of chlorophyll $\mathrm{a}+\mathrm{b}$ by $5.43 \%$ and $11.37 \%$ in $\mathrm{N} 1$ and $\mathrm{N} 2$, respectively. For C30, C50, C70 and C90, there was no significant difference in chlorophyll $\mathrm{a}+\mathrm{b}$ between N1 and N2 in both 2017 and 2018.

\subsection{Tomato Yield}

Biochar, nitrogen fertilizer, year and their interactions $(\mathrm{N} \times \mathrm{C}, \mathrm{Y} \times \mathrm{N}, \mathrm{Y} \times \mathrm{C}, \mathrm{Y} \times \mathrm{N} \times \mathrm{C})$ had significant effects on tomato yield (Table 1). In general, the tomato yield first increased and then decreased as the amount of applied biochar increased. And it reached the maximum at C50 for both the N1 and N2 groups in 2017 and 2018 (Figure 3).

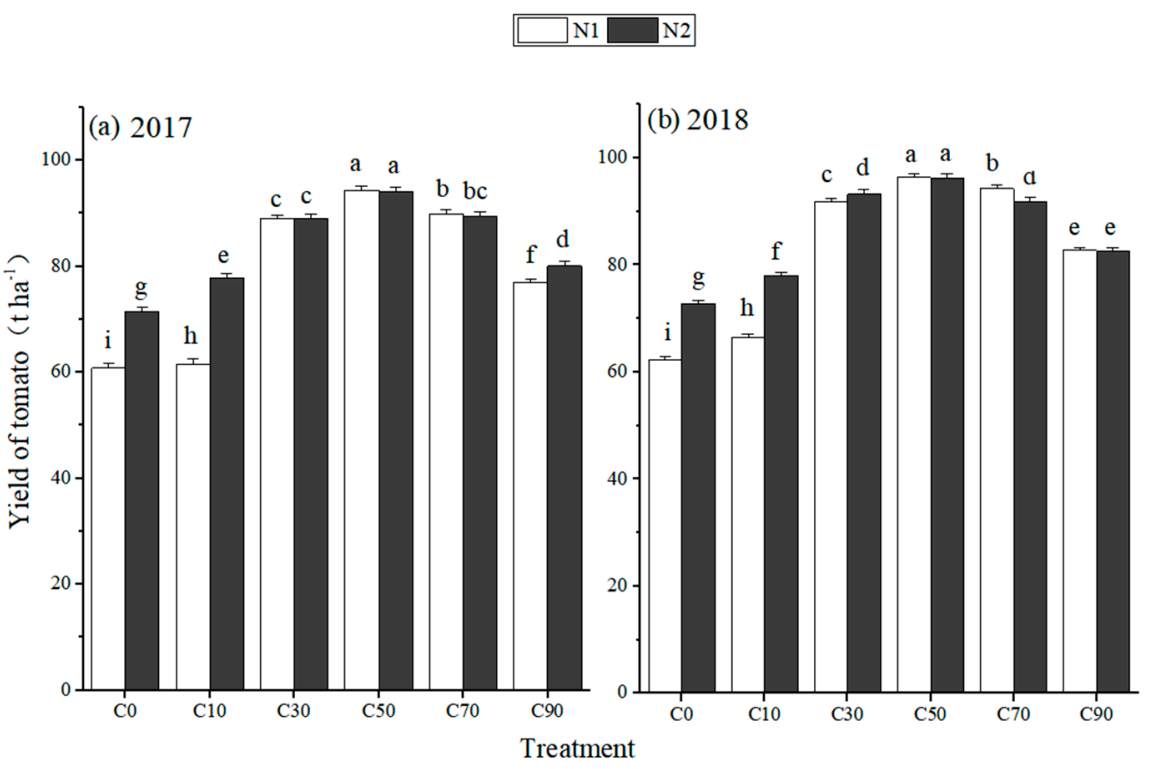

Figure 3. The effect of biochar on tomato yield under low (N1) and normal (N2) nitrogen fertilization in 2017 (a) and 2018 (b). Different lowercase letters denote significant differences among treatment means at the 0.05 level by the Duncan's MRT method.

In 2017, the C10, C30, C50, C70 and C90 in the N1 treatment group increased tomato yield by $1.31 \%, 46.29 \%, 55.24 \%, 47.81 \%$ and $26.58 \%$, with respect to C0. The tomato yield of N1C50 reached the maximum. Compared with C0, the tomato yield of C10, C30, C50, C70 and C90 in the N2 treatment group increased by $8.83 \%, 24.55 \%, 31.49 \%, 25.04 \%$ and $11.91 \%$, and the N2C50 was the maximum. For C30, C50 and C70, there was no significant difference in tomato yield between $\mathrm{N} 1$ and $\mathrm{N} 2$.

In 2018, the $\mathrm{C} 10, \mathrm{C} 30, \mathrm{C} 50, \mathrm{C} 70$ and $\mathrm{C} 90$ in the $\mathrm{N} 1$ treatment group increased tomato yield by $6.65 \%, 45.76 \%, 54.79 \%, 51.27 \%$ and $32.80 \%$, with respect to $\mathrm{C} 0$. The tomato yield of $\mathrm{N} 1 \mathrm{C} 50$ reached the maximum. Compared with $\mathrm{C} 0$, the tomato yield of $\mathrm{C} 10, \mathrm{C} 30, \mathrm{C} 50, \mathrm{C} 70$ and C90 in the N2 treatment group increased by $7.32 \%, 28.26 \%, 32.33 \%, 26.38 \%$ and $13.53 \%$, and the $\mathrm{N} 2 \mathrm{C} 50$ was the maximum. For $\mathrm{C} 50$ and $\mathrm{C} 90$, there was no significant difference in tomato yield between $\mathrm{N} 1$ and $\mathrm{N} 2$. 
Therefore, C50 was the best biochar application rate for both $\mathrm{N} 1$ and N2 group, which always resulted in the highest increase in tomato yield in comparison with C0. Furthermore, it was important to notice that $\mathrm{N}$ fertilizer reduction (from N2 to N1) did not decrease the yield.

\subsection{The Relationship between Nutrient Uptake, Pn and Tomato Yield}

The regression analysis exhibited a significant linear correlation between total N accumulation and Pn (Figure 4) for both the N1 and N2 groups in 2017 and 2018. The $\mathrm{R}^{2}$ value between total $\mathrm{N}$ accumulation and Pn was 0.97 and 0.80 in the N1 group in 2017 and 2018, respectively, 0.91 and 0.95 in the N2 group in 2017 and 2018, respectively. Similar to the total $\mathrm{N}$ accumulation, the total $\mathrm{P}$ accumulation also had a significant linear correlation with Pn. The $\mathrm{R}^{2}$ value between total P accumulation and Pn was 0.80 and 0.81 in the N1 group in 2017 and 2018, and 0.88 and 0.83 in the N2 group in 2017 and 2018. High positive linear correlations also occurred between $\mathrm{Pn}$ and tomato yield. The $\mathrm{R}^{2}$ value between Pn and tomato yield was 0.95 and 0.88 in the N1 group in 2017 and 2018, and 0.96 and 0.97 in the N2 group in 2017 and 2018.
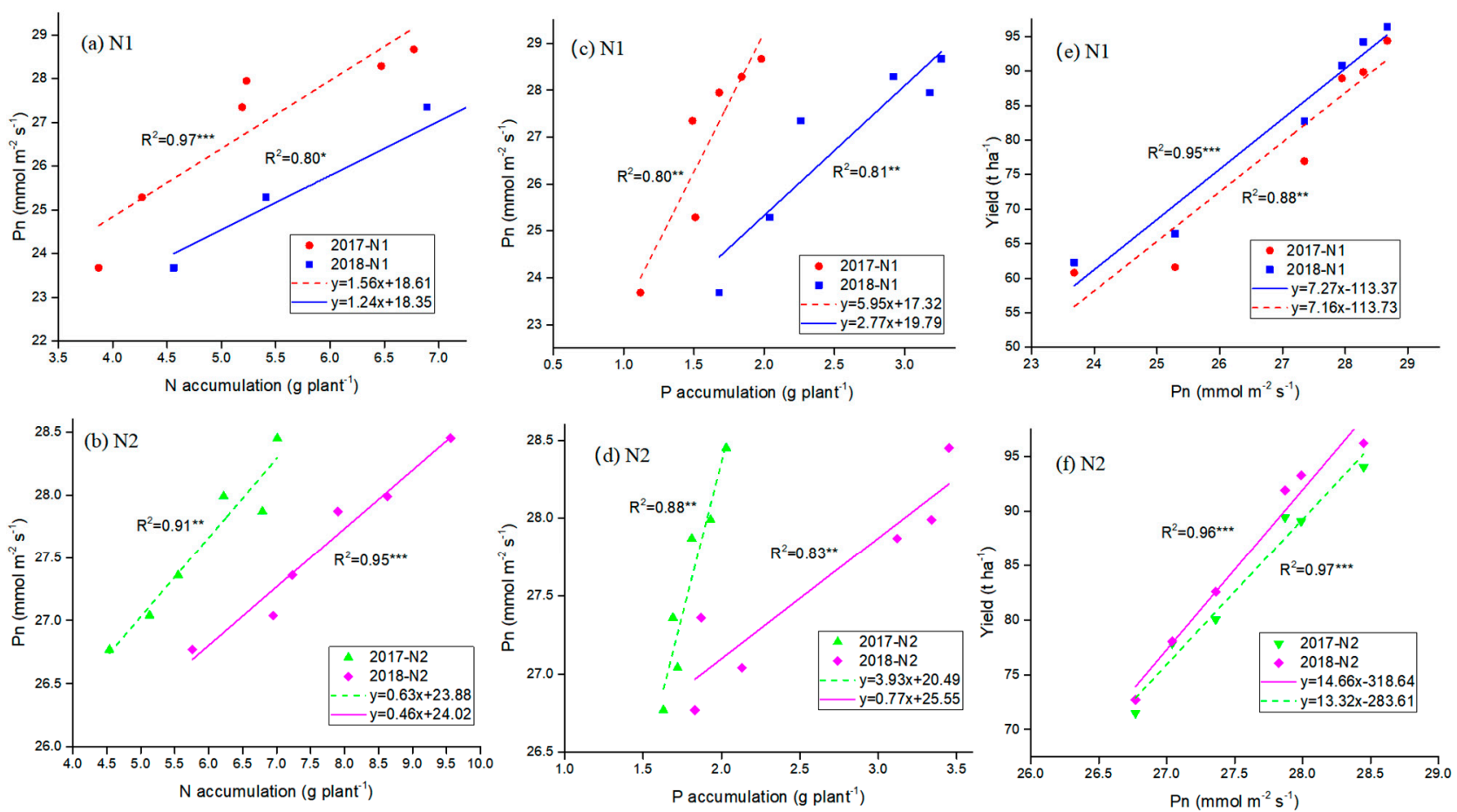

Figure 4. Relationship between total $\mathrm{N}$ accumulation and Pn $(\mathbf{a}, \mathbf{b})$, total $\mathrm{P}$ accumulation and Pn (c,d), and Pn and tomato yield $(\mathbf{e}, \mathbf{f})$ in 2017 and 2018. ${ }^{*}{ }^{* *},{ }^{* * *}$ represents significant correlations at the $p<0.05, p<0.01, p<0.001$ level.

\subsection{PCA Analysis for Nutrient Uptake, Photosynthetic Traits and Tomato Yield}

Principal component analyses results (Figure 5) showed that PC1 and PC2 explained $92.71 \%$ of the total variation in 2017 and $94.46 \%$ of the total variation in 2018 . Among them, PC1 explained $67.31 \%$ and $56.20 \%$, while PC2 explained $25.40 \%$ and $38.26 \%$ in 2017 and 2018, respectively. All of the N1 and N2 treatment combined with C0, C10 and C90, located at the left side of the y axis. All the N1 and N2 treatments combined with C30, C50 and C70, located at the right side of the y axis, and the parameters N, P, Pn, gs, Tr, chlorophyll a, $\mathrm{b}, \mathrm{a}+\mathrm{b}$ and yield were also located at the right side of the $\mathrm{y}$ axis. This indicated that $\mathrm{C} 0$, C10 and C90 treatments limited the capacity of nutrient uptakes, photosynthetic traits and tomato yield, while C30, C50 and C70 had a significant positive effect on the capacity of nutrient uptakes, photosynthetic traits and tomato yield. 

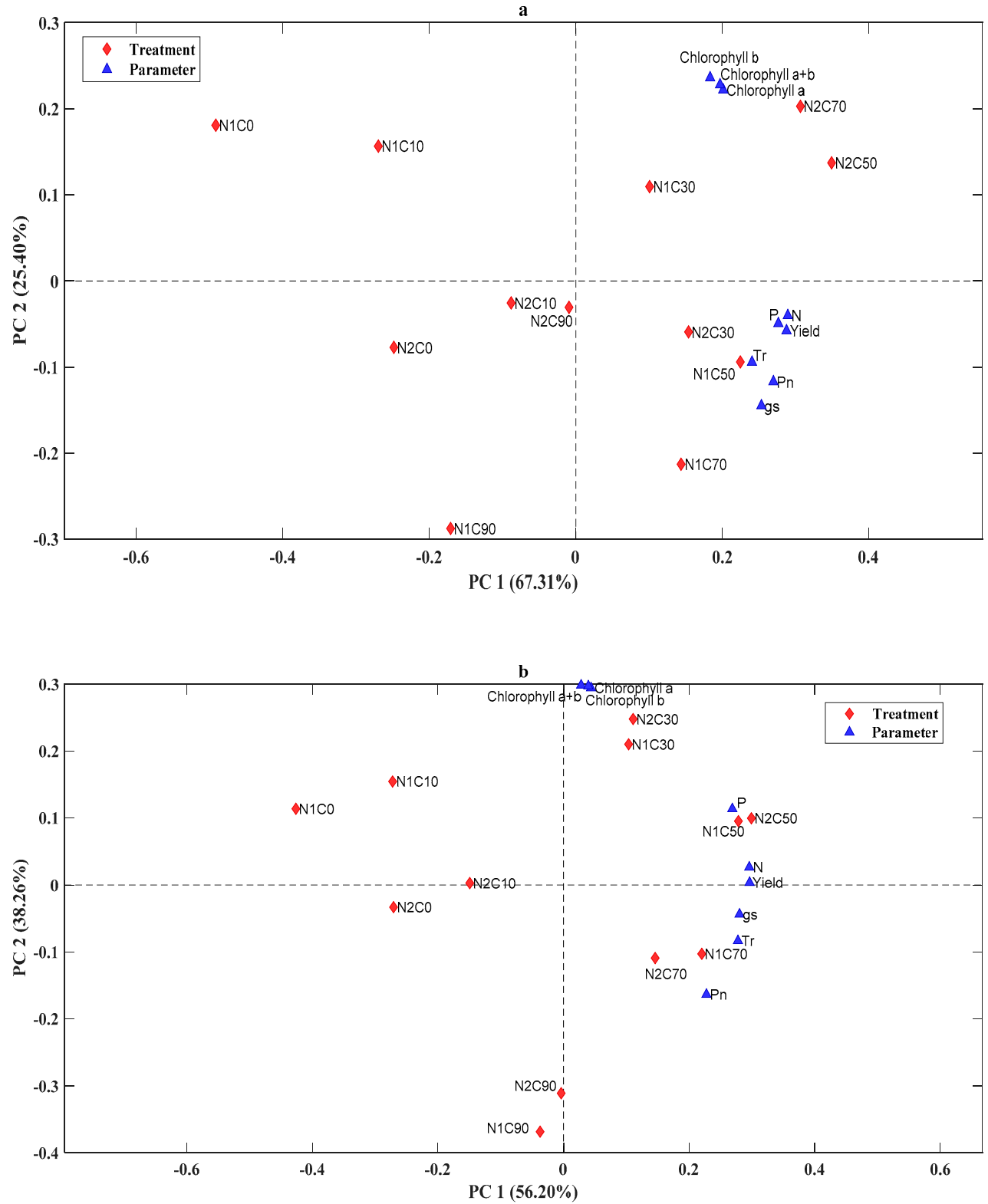

Figure 5. Principal component analyses of the nutrient uptake, photosynthetic pigments, gas exchange parameters and tomato yield in response to biochar and N application in 2017 (a) and 2018 (b).

\section{Discussion}

\subsection{Effect of Biochar on Nutrients Uptake ( $N$ and $P$ ) of Tomato Plants}

This study showed that biochar application can significantly increase the accumulation and uptake of $\mathrm{N}$ and $\mathrm{P}$ in tomato plants (Figures 1 and 2). This may be because biochar affected the soil environment and the physicochemical properties of the soil [40]. It has been reported that biochar can promote the hydrolysis reactions of urea fertilizer and the transformation of $\mathrm{N}$ by affecting urease activity [36]. Moreover, the use of biochar can promote phosphatase activity and increase the available phosphorus content in the soil [41]. These significantly improve the nutrient supply capacity for tomato plants. Additionally, biochar increased the nutrient holding capacity [42]. The abundant surface area of biochar was valuable for adsorbing nutrients and prolonging the retention time of nutrients, which also promoted the nutrient absorption of tomato plants. It is necessary to mention that $\mathrm{N}$ excess may exacerbate unbalanced vegetative plant growth [30], which should be taken into account when biochar amendment is applied together with $\mathrm{N}$. 


\subsection{Effect of Biochar on Chlorophyll Content and Gas Exchange Parameters of Tomato}

Leaf chlorophyll content and leaf gas exchange intensity directly determine the photosynthetic characteristics of plants [43]. Photosynthetic characteristics of plants are mainly affected by changes in soil environment, moisture and nutrients [44]. Some studies have shown that biochar has the potential of improving the photosynthetic capacity of crop leaves $[45,46]$. Our study found that adding biochar to the soil significantly increased leaf gas exchange parameters (Table 2) and leaf chlorophyll content (Table 3), thus the photosynthetic characteristics of tomato leaves were significantly improved. The reason may be due to the ability of biochar in changing the soil environment and further enhancing the nutrients uptake by tomato plants, and this resulted in the enhancement of photosynthetic rate [47]. Previous studies also exhibited that the leaf chlorophyll content is significantly affected by plant nutrient content [48], which supports our study. Our study showed a significant positive correlation between total N and P accumulation and Pn (Figure 4), which meant that biochar enhanced tomato photosynthetic characteristics by increasing tomato plant $\mathrm{N}$ and $\mathrm{P}$ accumulation. Similar to Pn, biochar application also increased gs and Tr. Apart from the reason of nutrient uptake, this increase may be also relevant to the water-holding capacity and physical properties of biochar [49]. In this study, we also demonstrated that applying higher biochar (e.g., C90) reduced the content of these parameters; that is to say that excessive biochar is not beneficial for improving the photosynthetic traits of tomato plants. A high application rate of biochar might limit nutrient accumulation, such as $\mathrm{N}$ and $\mathrm{P}$, and then the high ratio of $\mathrm{C} / \mathrm{N}$ could lead to nitrogen immobilization [50], which decreased the leaf photosynthesis of tomato plants. Therefore, a certain amount of biochar application can improve nutrient uptake by tomato plants and further enhance leaf photosynthesis.

\subsection{Effect of Biochar on Tomato Yield}

In this study, biochar application significantly increased tomato yield (Figure 3). Photosynthetic characteristic is one of the most important factors in increasing crop yield [51]. Figure 4 exhibited a significant positive correlation between Pn and tomato yield, which meant that biochar can increase tomato yield by improving the photosynthetic characteristics of tomato plants. This was reinforced by other studies [46]. Moreover, different biochar application rates had different effects on different crops. Chan, et al. [52] demonstrated that the yield of radish increased by $266 \%$ when $100 \mathrm{t} \mathrm{ha}^{-1}$ biochar was added. Blackwell, et al. [53] found that adding $1 \mathrm{t} \mathrm{ha}^{-1}$ of biochar could significantly increase wheat yield. However, Asai, et al. [50] exposed that the yield of rice was significantly reduced when the applied biochar was more than $16 \mathrm{tha}^{-1}$. In this study, $50 \mathrm{t} \mathrm{ha}^{-1}$ biochar resulted in the highest tomato yield for both the N1 and N2 application groups. Lévesque, et al. [25] also reported that adding 5-15\% biochar increased tomato yield by up to $32 \%$ in a peat-based growing medium. On the contrary, Vaccari, et al. [28] argued that adding $14 \mathrm{tha}^{-1}$ biochar did not increase the yield of processing tomato; similar conclusions can be found in Massa, et al. [27]. The reason for these differences was not only due to crop species but also caused by the types of biochar, strategy of biochar and $\mathrm{N}$ application, soil characteristics, stress conditions, environmental changes and test area etc. Moreover, the tomato yield showed a trend of first increasing and then decreasing as the applied biochar increased in this study. The excessive biochar (e.g., $90 \mathrm{t} \mathrm{ha}^{-1}$ ) led to nutrient immobilization and reduced the nutrient accumulation in the plant, which was not conducive to the photosynthetic characteristics of the plant and led to a lower yield [46]

Finally, it is worth mentioning that the amount of applied nitrogen fertilizer can be significantly reduced without reducing the tomato yield when a certain amount of biochar was introduced (Figure 3). Similar patterns can be observed for nutrient uptake, gas exchange parameters and photosynthetic pigments. Zhu, et al. [54] and Guo, et al. [36] are in accordance with our results. Generally, a significant reduction of $\mathrm{N}$ supply has a negative effect on tomato yield [29], even though it was recently reported that the effect may differ depending on the growing stages that the reduction was imposed [31]. When biochar was added into the soil, it increased the retention of available nitrogen and promoted 
the conversion of nitrogen by affecting soil microbial characteristics, which meant that reducing a certain amount of applied nitrogen fertilizer may not affect the conversion rate of nitrogen significantly when a certain amount of biochar was added. However, excessive reduction of nitrogen fertilizer may lead to a systematic insufficiency of nitrogen in tomato plants and result in a loss of yield.

\section{Conclusions}

Biochar application has a significant positive effect on the nutrient uptake, photosynthetic traits and tomato yield. The highest gains of most parameters occurred at C50 (50 $\mathrm{t} \mathrm{ha}^{-1}$ ) biochar application rate. C50 significantly improved the nutrient uptake by tomato plants and further enhanced the photosynthetic traits of tomato leaves, which led to the highest gains in tomato yield. In this case, more than $50 \%$ increase of yield was achieved even though the applied nitrogen fertilizer was significantly reduced (from $250 \mathrm{~kg} \mathrm{ha}^{-1}$ to $190 \mathrm{~kg} \mathrm{ha}^{-1}$ ). The results agree with our proposed hypothesis. As a conclusion, $50 \mathrm{t} \mathrm{ha}^{-1}$ biochar and $190 \mathrm{~kg} \mathrm{ha}^{-1}$ nitrogen fertilizer were recommended as a proper choice for local farmers. The results will clearly enhance the understandings about the effect of biochar on photosynthesis and tomato yield and be of importance for practical agricultural management. This research is limited to a specific type of biochar and soil. However, different types of biochar may have diverse effects on tomato, and varieties of soil may also lead to significant differences in the results. It will be interesting to investigate the effects of biochar varieties and soil varieties on the photosynthetic traits of tomato plants and tomato yield. Moreover, a wider range of parameters and their complex relations could be studied to deeply understand the response mechanism of photosynthesis and tomato yield to biochar addition in the future.

Author Contributions: Conceptualization, L.G.; methodology, J.W.; software, H.Y.; validation, M.K.; formal analysis, M.K. and J.W.; investigation, L.G.; data curation, L.G.; visualization, H.Y.; writingoriginal draft preparation, L.G. and H.Y.; writing—review and editing, L.G. and H.Y. All authors have read and agreed to the published version of the manuscript.

Funding: This research was funded by the National Key Research and Development Project (grant number: 2016YFC0400202) and the National Natural Science Foundation Program (grant number: 51679205).

Data Availability Statement: Not applicable.

Acknowledgments: Lili Guo appreciates the Chinese Scholarship Council (CSC) for supporting her study at the Faculty of Science, University of Copenhagen, Denmark.

Conflicts of Interest: The authors declare no conflict of interest.

\section{References}

1. Liu, H.; Li, H.; Ning, H.; Zhang, X.; Li, S.; Pang, J.; Wang, G.; Sun, J. Optimizing irrigation frequency and amount to balance yield, fruit quality and water use efficiency of greenhouse tomato. Agric. Water Manag. 2019, 226, 105787. [CrossRef]

2. Nicola, S.; Tibaldi, G.; Fontana, E.; Crops, A.-V.; Plants, A. Tomato production systems and their application to the tropics. Proc. IS Tomato Trop. Acta Hortic. 2009, 821, 27-33. [CrossRef]

3. Han, P.; Bayram, Y.; Shaltiel-Harpaz, L.; Sohrabi, F.; Saji, A.; Esenali, U.T.; Jalilov, A.; Ali, A.; Shashank, P.R.; Ismoilov, K. Tuta absoluta continues to disperse in Asia: Damage, ongoing management and future challenges. J. Pest Sci. 2019, 92, 1317-1327. [CrossRef]

4. He, Z.; Li, M.; Cai, Z.; Zhao, R.; Hong, T.; Yang, Z.; Zhang, Z. Optimal irrigation and fertilizer amounts based on multi-level fuzzy comprehensive evaluation of yield, growth and fruit quality on cherry tomato. Agric. Water Manag. 2021, 243, 106360. [CrossRef]

5. Fanwoua, J.; Vercambre, G.; Buck-Sorlin, G.; Dieleman, J.A.; de Visser, P.; Génard, M. Supplemental LED lighting affects the dynamics of tomato fruit growth and composition. Sci. Hortic. 2019, 256, 108571. [CrossRef]

6. Guo, L.; Bornø, M.L.; Niu, W.; Liu, F. Biochar amendment improves shoot biomass of tomato seedlings and sustains water relations and leaf gas exchange rates under different irrigation and nitrogen regimes. Agric. Water Manag. 2021, $245,106580$. [CrossRef]

7. Ghorbani, M.; Amirahmadi, E.; Zamanian, K. In-situ biochar production in paddies: Direct involvement of farmers in greenhouse gases reduction policies besides increasing nutrients availability and rice production. Land Degrad. Dev. 2021. [CrossRef]

8. Kwoczynski, Z.; Čmelík, J. Characterization of biomass wastes and its possibility of agriculture utilization due to biochar production by torrefaction process. J. Clean. Prod. 2021, 280, 124302. [CrossRef] 
9. Zheng, Y.; Wang, B.; Wester, A.E.; Chen, J.; He, F.; Chen, H.; Gao, B. Reclaiming phosphorus from secondary treated municipal wastewater with engineered biochar. Chem. Eng. J. 2019, 362, 460-468. [CrossRef]

10. Wang, Q.; Wang, B.; Lee, X.; Lehmann, J.; Gao, B. Sorption and desorption of $\mathrm{Pb}$ (II) to biochar as affected by oxidation and pH. Sci. Total Environ. 2018, 634, 188-194. [CrossRef] [PubMed]

11. Zhibin, L.; Liu, Q.; Liu, G.; Cowie, A.L.; Bei, Q.; Liu, B.; Wang, X.; Ma, J.; Zhu, J.; Xie, Z. Effects of different biochars on Pinus elliottii growth, $\mathrm{N}$ use efficiency, soil $\mathrm{N}_{2} \mathrm{O}$ and $\mathrm{CH}_{4}$ emissions and $\mathrm{C}$ storage in a subtropical area of China. Pedosphere 2017, 27, 248-261.

12. Farhangi-Abriz, S.; Torabian, S.; Qin, R.; Noulas, C.; Lu, Y.; Gao, S. Biochar effects on yield of cereal and legume crops using meta-analysis. Sci. Total Environ. 2021, 775, 145869. [CrossRef]

13. Huang, H.; Reddy, N.G.; Huang, X.; Chen, P.; Wang, P.; Zhang, Y.; Huang, Y.; Lin, P.; Garg, A. Effects of pyrolysis temperature, feedstock type and compaction on water retention of biochar amended soil. Sci. Rep. 2021, 11, 1-19.

14. Alling, V.; Hale, S.E.; Martinsen, V.; Mulder, J.; Smebye, A.; Breedveld, G.D.; Cornelissen, G. The role of biochar in retaining nutrients in amended tropical soils. J. Plant Nutr. Soil Sci. 2014, 177, 671-680. [CrossRef]

15. Angst, T.E.; Sohi, S.P. Establishing release dynamics for plant nutrients from biochar. GCB Bioenergy 2013, 5, 221-226. [CrossRef]

16. Oladele, S.; Adeyemo, A.; Awodun, M. Influence of rice husk biochar and inorganic fertilizer on soil nutrients availability and rain-fed rice yield in two contrasting soils. Geoderma 2019, 336, 1-11. [CrossRef]

17. Zheng, H.; Wang, Z.; Deng, X.; Herbert, S.; Xing, B. Impacts of adding biochar on nitrogen retention and bioavailability in agricultural soil. Geoderma 2013, 206, 32-39. [CrossRef]

18. Ali, I.; Ullah, S.; He, L.; Zhao, Q.; Iqbal, A.; Wei, S.; Shah, T.; Ali, N.; Bo, Y.; Adnan, M. Combined application of biochar and nitrogen fertilizer improves rice yield, microbial activity and N-metabolism in a pot experiment. PeerJ 2020, 8, e10311. [CrossRef] [PubMed]

19. Rizwan, M.; Ali, S.; Abbas, T.; Adrees, M.; Zia-ur-Rehman, M.; Ibrahim, M.; Abbas, F.; Qayyum, M.F.; Nawaz, R. Residual effects of biochar on growth, photosynthesis and cadmium uptake in rice (Oryza sativa L.) under Cd stress with different water conditions. J. Environ. Manag. 2018, 206, 676-683. [CrossRef]

20. Qian, Z.; Kong, L.-J.; Shan, Y.-Z.; Yao, X.-D.; Zhang, H.-J.; Xie, F.-T.; Xue, A. Effect of biochar on grain yield and leaf photosynthetic physiology of soybean cultivars with different phosphorus efficiencies. J. Integr. Agric. 2019, 18, 2242-2254.

21. Abideen, Z.; Koyro, H.-W.; Huchzermeyer, B.; Bilquees, G.; Khan, M.A. Impact of a biochar or a biochar-compost mixture on water relation, nutrient uptake and photosynthesis of Phragmites karka. Pedosphere 2020, 30, 466-477. [CrossRef]

22. Bruun, E.W.; Petersen, C.T.; Hansen, E.; Holm, J.K.; Hauggaard-Nielsen, H. Biochar amendment to coarse sandy subsoil improves root growth and increases water retention. Soil Use Manag. 2014, 30, 109-118. [CrossRef]

23. Nemeskéri, E.; Molnár, K.; Helyes, L. Relationships of spectral traits with yield and nutritional quality of snap beans (Phaseolus vulgaris L.) in dry seasons. Arch. Agron. Soil Sci. 2018, 64, 1222-1239. [CrossRef]

24. Nemeskéri, E.; Neményi, A.; Bőcs, A.; Pék, Z.; Helyes, L. Physiological factors and their relationship with the productivity of processing tomato under different water supplies. Water 2019, 11, 586. [CrossRef]

25. Lévesque, V.; Jeanne, T.; Dorais, M.; Ziadi, N.; Hogue, R.; Antoun, H. Biochars improve tomato and sweet pepper performance and shift bacterial composition in a peat-based growing medium. Appl. Soil Ecol. 2020, 153, 103579. [CrossRef]

26. Graber, E.R.; Harel, Y.M.; Kolton, M.; Cytryn, E.; Silber, A.; David, D.R.; Tsechansky, L.; Borenshtein, M.; Elad, Y. Biochar impact on development and productivity of pepper and tomato grown in fertigated soilless media. Plant Soil 2010, 337, 481-496. [CrossRef]

27. Massa, D.; Bonetti, A.; Cacini, S.; Faraloni, C.; Prisa, D.; Tuccio, L.; Petruccelli, R. Soilless tomato grown under nutritional stress increases green biomass but not yield or quality in presence of biochar as growing medium. Hortic. Environ. Biotechnol. 2019, 60, 871-881. [CrossRef]

28. Vaccari, F.; Maienza, A.; Miglietta, F.; Baronti, S.; Di Lonardo, S.; Giagnoni, L.; Lagomarsino, A.; Pozzi, A.; Pusceddu, E.; Ranieri, R. Biochar stimulates plant growth but not fruit yield of processing tomato in a fertile soil. Agric. Ecosyst. Environ. 2015, 207, 163-170. [CrossRef]

29. Bénard, C.; Gautier, H.; Bourgaud, F.; Grasselly, D.; Navez, B.; Caris-Veyrat, C.; Weiss, M.; Génard, M. Effects of low nitrogen supply on tomato (Solanum lycopersicum) fruit yield and quality with special emphasis on sugars, acids, ascorbate, carotenoids, and phenolic compounds. J. Agric. Food Chem. 2009, 57, 4112-4123. [CrossRef]

30. Elia, A.; Conversa, G. Agronomic and physiological responses of a tomato crop to nitrogen input. Eur. J. Agron. 2012, 40, 64-74. [CrossRef]

31. Hernández, V.; Hellín, P.; Fenoll, J.; Flores, P. Impact of nitrogen supply limitation on tomato fruit composition. Sci. Hortic. 2020, 264, 109173. [CrossRef]

32. Peat, W. Relationships between photosynthesis and light intensity in the tomato. Ann. Bot. 1970, 34, 319-328. [CrossRef]

33. Nogués, S.; Cotxarrera, L.; Alegre, L.; Trillas, M.I. Limitations to photosynthesis in tomato leaves induced by Fusarium wilt. New Phytol. 2002, 154, 461-470. [CrossRef]

34. Nunes-Nesi, A.; Carrari, F.; Gibon, Y.; Sulpice, R.; Lytovchenko, A.; Fisahn, J.; Graham, J.; Ratcliffe, R.G.; Sweetlove, L.J.; Fernie, A.R. Deficiency of mitochondrial fumarase activity in tomato plants impairs photosynthesis via an effect on stomatal function. Plant J. 2007, 50, 1093-1106. [CrossRef] [PubMed]

35. Du, Y.-D.; Zhang, Q.; Cui, B.-J.; Sun, J.; Wang, Z.; Ma, L.-H.; Niu, W.-Q. Aerated irrigation improves tomato yield and nitrogen use efficiency while reducing nitrogen application rate. Agric. Water Manag. 2020, 235, 106152. [CrossRef] 
36. Guo, L.; Yu, H.; Niu, W.; Kharbach, M. Biochar Promotes Nitrogen Transformation and Tomato Yield by Regulating NitrogenRelated Microorganisms in Tomato Cultivation Soil. Agronomy 2021, 11, 381. [CrossRef]

37. Dayong, T.; Xuandong, W.; Qin, X. The Mensuration of Eight Kinds Mineral Matters Contents of Partial Plants in Tarim Basin. Chin. Agric. Sci. Bull. 2006, 4, 137-140.

38. Thwe, A.A.; Vercambre, G.; Gautier, H.; Gay, F.; Phattaralerphong, J.; Kasemsap, P. Response of photosynthesis and chlorophyll fluorescence to acute ozone stress in tomato (Solanum lycopersicum Mill.). Photosynthetica 2014, 52, 105-116. [CrossRef]

39. Gitelson, A.A.; Zur, Y.; Chivkunova, O.B.; Merzlyak, M.N. Assessing carotenoid content in plant leaves with reflectance spectroscopy. Photochem. Photobiol. 2002, 75, 272-281. [CrossRef]

40. Zhang, Y.; Wang, J.; Feng, Y. The effects of biochar addition on soil physicochemical properties: A review. Catena 2021, $202,105284$. [CrossRef]

41. Mukherjee, S.; Mavi, M.S.; Singh, J.; Singh, B.P. Rice-residue biochar influences phosphorus availability in soil with contrasting P status. Arch. Agron. Soil Sci. 2020, 66, 778-791. [CrossRef]

42. El-Naggar, A.; El-Naggar, A.H.; Shaheen, S.M.; Sarkar, B.; Chang, S.X.; Tsang, D.C.; Rinklebe, J.; Ok, Y.S. Biochar compositiondependent impacts on soil nutrient release, carbon mineralization, and potential environmental risk: A review. J. Environ. Manag. 2019, 241, 458-467. [CrossRef]

43. Han, S.-H.; Kim, D.-H.; Kim, G.N.; Byun, J.-K. Changes of leaf characteristics, pigment content and photosynthesis of Forsythia saxatilis under two different light intensities. J. Korean Soc. For. Sci. 2011, 100, 609-615.

44. Van Roekel, R.; Purcell, L. Understanding and increasing soybean yields. In Proceedings of the Integrated Crop Management Conference, Ames, IA, USA, 1 December 2016.

45. Rehman, M.Z.-u.; Rizwan, M.; Ali, S.; Fatima, N.; Yousaf, B.; Naeem, A.; Sabir, M.; Ahmad, H.R.; Ok, Y.S. Contrasting effects of biochar, compost and farm manure on alleviation of nickel toxicity in maize (Zea mays L.) in relation to plant growth, photosynthesis and metal uptake. Ecotoxicol. Environ. Saf. 2016, 133, 218-225. [CrossRef] [PubMed]

46. Wang, S.; Zheng, J.; Wang, Y.; Yang, Q.; Chen, T.; Chen, Y.; Chi, D.; Xia, G.; Siddique, K.H.; Wang, T. Photosynthesis, Chlorophyll Fluorescence, and Yield of Peanut in Response to Biochar Application. Front. Plant Sci. 2021, 12, 1000.

47. He, Y.; Yao, Y.; Ji, Y.; Deng, J.; Zhou, G.; Liu, R.; Shao, J.; Zhou, L.; Li, N.; Zhou, X. Biochar amendment boosts photosynthesis and biomass in C3 but not C4 plants: A global synthesis. GCB Bioenergy 2020, 12, 605-617. [CrossRef]

48. Mauromicale, G.; Ierna, A.; Marchese, M. Chlorophyll fluorescence and chlorophyll content in field-grown potato as affected by nitrogen supply, genotype, and plant age. Photosynthetica 2006, 44, 76-82. [CrossRef]

49. Laghari, M.; Mirjat, M.S.; Hu, Z.; Fazal, S.; Xiao, B.; Hu, M.; Chen, Z.; Guo, D. Effects of biochar application rate on sandy desert soil properties and sorghum growth. Catena 2015, 135, 313-320. [CrossRef]

50. Asai, H.; Samson, B.K.; Stephan, H.M.; Songyikhangsuthor, K.; Homma, K.; Kiyono, Y.; Inoue, Y.; Shiraiwa, T.; Horie, T. Biochar amendment techniques for upland rice production in Northern Laos: 1. Soil physical properties, leaf SPAD and grain yield. Field Crop. Res. 2009, 111, 81-84. [CrossRef]

51. Xie, X.; Li, B.; Shen, S. Impact of high temperature stress on photosynthetic characteristic and yield of rice (Oryza sativa) at heading. Indian J. Agric. Sci. 2012, 82, 516-522.

52. Chan, K.Y.; Van Zwieten, L.; Meszaros, I.; Downie, A.; Joseph, S. Agronomic values of greenwaste biochar as a soil amendment. Soil Res. 2007, 45, 629-634. [CrossRef]

53. Blackwell, P.; Krull, E.; Butler, G.; Herbert, A.; Solaiman, Z. Effect of banded biochar on dryland wheat production and fertiliser use in south-western Australia: An agronomic and economic perspective. Soil Res. 2010, 48, 531-545. [CrossRef]

54. Zhu, X.; Chen, B.; Zhu, L.; Xing, B. Effects and mechanisms of biochar-microbe interactions in soil improvement and pollution remediation: A review. Environ. Pollut. 2017, 227, 98-115. [CrossRef] [PubMed] 